\title{
Plasma neutralization properties of the SARS-CoV-2 Omicron variant
}

Fabian Schmidt ${ }^{1 \#}$, Frauke Muecksch ${ }^{1 \#}$, Yiska Weisblum ${ }^{1 \#}$, Justin Da Silva $^{1}$, Eva Bednarski ${ }^{1}$, Alice $\mathrm{Cho}^{2}$, Zijun Wang ${ }^{2}$, Christian Gaebler ${ }^{2}$, Marina Caskey², Michel C. Nussenzweig ${ }^{2,3^{*}}$,

Theodora Hatziioannou ${ }^{1 *}$, Paul D. Bieniasz ${ }^{1,3 *}$

${ }^{1}$ Laboratory of Retrovirology, The Rockefeller University, New York, NY 10065, USA.

${ }^{2}$ Laboratory of Molecular Immunology, The Rockefeller University, New York, NY 10065, USA.

${ }^{3}$ Howard Hughes Medical Institute

"Equal contribution

*Corresponding authors. Email: nussen@rockefeller.edu or thatziio@rockefeller.edu, or pbieniasz@rockefeller.edu 


\section{Abstract \\ BACKGROUND}

The Omicron SARS-CoV-2 variant has spread internationally and is responsible for rapidly increasing case numbers. The emergence of divergent variants in the context of a heterogeneous and evolving neutralizing antibody response in host populations might compromise protection afforded by vaccines or prior infection.

\section{METHODS}

We measured neutralizing antibody titers in 169 longitudinally collected plasma samples using pseudotypes bearing the Wuhan-hu-1 or the Omicron variant or a laboratory-designed neutralization-resistant SARS-CoV-2 spike (PMS20). Plasmas were obtained from convalescents who did or did not subsequently receive an mRNA vaccine, or naive individuals who received 3-doses of mRNA or 1-dose Ad26 vaccines. Samples were collected approximately 1, 5-6 and 12 months after initial vaccination or infection.

\section{RESULTS}

Like PMS20, the Omicron spike protein was substantially resistant to neutralization compared to Wuhan-hu-1. In convalescent plasma the median deficit in neutralizing activity against PMS20 or Omicron was 30- to 60-fold. Plasmas from recipients of 2 mRNA vaccine doses were 30 - to 180- fold less potent against PMS20 and Omicron than Wuhan-hu-1. Notably, previously infected or two-mRNA dose vaccinated individuals who received additional mRNA vaccine dose(s) had 38 to 154 -fold and 35 to 214 -fold increases in neutralizing activity against Omicron and PMS20 respectively.

\section{CONCLUSIONS}

Omicron exhibits similar distribution of sequence changes and neutralization resistance as does a laboratory-designed neutralization-resistant spike protein, suggesting natural evolutionary pressure to evade the human antibody response. Currently available mRNA 
vaccine boosters, that may promote antibody affinity maturation, significantly ameliorate SARSCoV-2 neutralizing antibody titers.

\section{Introduction}

The recent emergence of the B.1.1.159 (Omicron) variant of SARS-CoV-2 ${ }^{1-3}$ has engendered widespread concern. Omicron has spread internationally and is responsible for rapidly increasing case numbers, particularly in South Africa ${ }^{3}$. Although the pathogenic potential of the new variant remains unclear ${ }^{3}$, a striking feature is the large number of amino acid substitutions, insertions and deletions in the spike protein (32 of the total of $~ 50$ nonsynonymous changes in the viral genome $)^{1}$ suggesting adaptation to substantial selective pressure. Some of the substitutions, for example those proximal to the furin cleavage site, are thought to be fitness enhancing and may facilitate virus spread ${ }^{4}$, but the majority of the changes are expected to reduce neutralizing antibody recognition.

The number of neutralizing epitopes targeted by polyclonal antibodies in SARS-CoV-2 convalescent or vaccinated individuals is an important determinant of the genetic barrier to viral escape $^{5}$. Whereas single monoclonal antibodies are prone to escape mutations, combinations targeting non-overlapping epitopes are more resistant to such changes ${ }^{6,7}$. There are numerous antibody targets in the SARS-CoV-2 spike protein, but polyclonal neutralizing responses are dominated by antibodies to the receptor binding domain (RBD) and the $\mathrm{N}$-terminal domain (NTD) of spike ${ }^{5,8-10}$. Indeed, aggregation of $\sim 20$ RBD and NTD mutations in a polymutant spike protein (PMS20) was required for evasion of polyclonal antibodies elicited in the majority of individuals who had been infected, or who had received two doses of an mRNA vaccine ${ }^{5,15}$. Notably, several of the changes in the PMS20 spike are the same or similar to the changes in 
medRxiv preprint doi: https://doi.org/10.1101/2021.12.12.21267646; this version posted December 13, 2021. The copyright holder for this preprint (which was not certified by peer review) is the author/funder, who has granted medRxiv a license to display the preprint in perpetuity.

It is made available under a CC-BY-NC-ND 4.0 International license .

the emergent Omicron variant spike ${ }^{11,12}$ (Figure 1A, B), leading to the prediction that Omicron would exhibit substantial antigenic escape.

Affinity maturation of individual SARS-CoV-2 neutralizing antibodies can dramatically alter their properties in ways that are pertinent for the emergence and control of variants ${ }^{13-16}$. The number of antibody variable region mutations and the binding affinity of antibodies increases over months and can vary depending on the nature of SARS-CoV-2 antigen exposure ${ }^{13,15-18}$. Indeed, affinity maturation can markedly expand SARS-CoV-2 neutralizing antibody breadth, enabling neutralization of SARS-CoV-2 variants that escape neutralization by corresponding ancestral antibodies and imposing a requirement for multiple amino acid substitutions for escape $\mathrm{e}^{7,13-15,18,19}$. Thus, Omicron has emerged in the context of a globally heterogeneous and evolving neutralizing antibody response in host populations that might provide varying degrees of protection, depending on infection and vaccination history. Here, we determined the ability of individuals with varying exposure to SARS-CoV-2 infection and vaccination, to neutralize SARSCoV-2 pseudotypes with spike proteins corresponding to the parental virus used in vaccine immunogens, PMS20 or the emergent Omicron variant.

\section{Methods}

\section{PLASMA SAMPLES}

The 169 plasma samples were from the following three longitudinal cohorts (Table 1): (i) Convalescent individuals who did or did not receive 2 doses of the Pfizer/BNT or Moderna mRNA vaccine between 6 months and 12 months after infection ${ }^{9,13,15}$; (ii) Uninfected individuals who received 3 doses of the Pfizer/BNT mRNA vaccine ${ }^{20}$; (iii) Uninfected individuals who received the J\&J Ad26 vaccine. Plasma samples were collected approximately 1, 5-6 and 12 months after initial vaccination or infection and selected for this study at random with respect to 
medRxiv preprint doi: https://doi.org/10.1101/2021.12.12.21267646; this version posted December 13, 2021. The copyright holder for this preprint (which was not certified by peer review) is the author/funder, who has granted medRxiv a license to display the preprint in perpetuity.

It is made available under a CC-BY-NC-ND 4.0 International license .

binding, neutralization titer, or donor demographic characteristics. The study visits and blood draws were reviewed and approved by the Institutional Review Board of the Rockefeller University (IRB no. DRO-1006, 'Peripheral Blood of Coronavirus Survivors to Identify VirusNeutralizing Antibodies').

\section{PSEUDOTYPE NEUTRALIZATION ASSAY}

The Omicron spike coding sequence was derived from sequence ID EPI_ISL_6640919. It was codon-optimized and synthesized as a C-terminally truncated $\Delta 19$ form in nine fragments (IDT). We also introduced a furin cleavage site mutation (R683G) that does not change the neutralization properties of the SASR-CoV-2 spike protein but enables higher titer pseudotyped viral stocks to be generated from transfected cells ${ }^{5}$. These synthetic DNA fragments, ranging in size from 444-599bp and a Nhel/Xbal-linearized pCR3.1 plasmid were Gibson assembled via 40bps overlapping sequences. Individual plasmid clones were completely sequenced (Illumina MiSeq) and a single correct clone was used in these studies. The Wuhan-hu-1 and PMS20 spike proteins were previously described ${ }^{5,21}$.

Neutralizing titers were measured using a SARS-CoV-2 pseudotyped HIV-1-based assay that recapitulates neutralizing titers obtained with authentic SARS-CoV-2 ${ }^{21}$. Plasmas were serially diluted (five-fold dilution interval) and then incubated with a SARS-CoV-2 spike (Wuhan-hu-1, PMS20 or Omicron) pseudotyped HIV-1 based nanoluc luciferase reporter virus for 1 hour at 37 ${ }^{\circ} \mathrm{C}$. The pseudotyped virus and antibody mixture was transferred to 96 well plates containing HT1080/ACE2.cl14 cells. After 48 hours, the cells were washed with PBS and lysed with Luciferase Cell Culture Lysis reagent (Promega). Then Nanoluc Luciferase activity in cell lysates was measured using the Nano-Glo Luciferase Assay System and a Glomax Navigator luminometer (Promega). The relative luminescence units were normalized to those measured in cells infected with the corresponding pseudotyped virus in the absence of plasma. The half- 
medRxiv preprint doi: https://doi.org/10.1101/2021.12.12.21267646; this version posted December 13, 2021. The copyright holder for this preprint (which was not certified by peer review) is the author/funder, who has granted medRxiv a license to display the preprint in perpetuity.

It is made available under a CC-BY-NC-ND 4.0 International license .

maximal plasma neutralizing titer $\left(\mathrm{NT}_{50}\right)$ was determined using four-parameter nonlinear regression (least squares regression method without weighting) (GraphPad Prism). The NT50 for each plasma was measured twice in two independent experiments, carried out by two different groups of researchers, with two technical replicates each.

\section{Results}

We measured plasma neutralizing antibody titers in 169 plasma samples from 47 individuals who have experienced diverse exposures to SARS-CoV-2 antigens (Table 1). Specifically, we measured titers of convalescent individuals who had been infected early in the pandemic, and whose plasma was donated an average of 1.3 and 6.2 months after infection (Supplementary Table S1). These individuals subsequently received one or two doses of an mRNA vaccine (Pfizer/BNT or Moderna) before collection of additional plasma samples approximately 12 months after initial infection. For comparison, we measured neutralizing titers in a group of convalescent individuals from the same initial cohort who were not vaccinated (Supplementary Table S1). We also measured neutralizing titers in uninfected individuals that received 2 doses of an mRNA vaccine (Pfizer/BNT or Moderna) and donated plasma at 1.2 and 5 months after the second dose. These same individuals received a third Pfizer/BNT dose booster $>6$ months after the second dose and donated another plasma sample 1 month after the third dose (Supplementary Table S2). Finally, we examined a cohort that received an Ad26 adenovirus vaccine $(\mathrm{J} \& \mathrm{~J})$ that has been widely deployed in the USA, at $\sim 1$ and 5 months after vaccination (Supplementary Table S2).

\section{NEUTRALIZATION OF PMS20 AND OMICRON PSEUDOTYPES BY CONVALESCENT PLASMA}

We found that, like PMS20, the Omicron variant pseudotyped virus was substantially resistant to neutralization by plasma compared to Wuhan-hu-1. In convalescent individuals whose plasmas 
medRxiv preprint doi: https://doi.org/10.1101/2021.12.12.21267646; this version posted December 13, 2021. The copyright holder for this preprint (which was not certified by peer review) is the author/funder, who has granted medRxiv a license to display the preprint in perpetuity.

It is made available under a CC-BY-NC-ND 4.0 International license .

were collected at $\sim 1.2$ months after infection, the median and range of the $\mathrm{NT}_{50}$ values was 2616 (681-19450), 49 (<25-429) and 68 (29-667) for the Wuhan-hu-1, PMS20 and Omicron spike proteins respectively (Figure $2 A)$. These values represent a mean $( \pm S D)$ fold reduction in $\mathrm{NT}_{50}$ of $60 \pm 47$-fold for PMS20 and 58 \pm 51 -fold for Omicron compared to Wuhan-hu-1. After 6 months of convalescence, the median and range of $\mathrm{NT}_{50}$ values from the same individuals was 1678 (321 - 5189), 28 (<25 - 248), and 42 (<25 - 428) for the Wuhan-hu-1, PMS20 and Omicron spike proteins respectively, corresponding to mean $( \pm S D)$ reductions in $N T_{50}$ of $37 \pm 27$-fold for PMS20 and 32 \pm 23 -fold for Omicron (Figure 2B). Similarly, plasmas collected from different individuals in the same cohort, 1 year after infection had $\mathrm{NT}_{50}$ values (median and range) of 2037 (127 - 25835), 76 (<25 - 907) and 136 (<25 - 667) for Wuhan-hu-1, PMS20 and Omicron pseudotypes, i.e. mean $( \pm S D)$ reductions in $N_{50}$ of $34 \pm 24$-fold for PMS20 and $43 \pm 23$-fold for Omicron (Figure 2C). Overall, individuals who were infected but not vaccinated show substantially reduced plasma neutralizing activity including many with sub detectable titers against Omicron pseudotypes.

\section{NEUTRALIZATION OF PMS20 AND OMICRON PSEUDOTYPES BY VACCINE RECIPIENT PLASMA}

Plasmas from vaccinated individuals also exhibited substantially impaired ability to neutralize the Omicron variant. In plasmas from individuals who received mRNA vaccines $\sim 1.3 \mathrm{~m}$ prior to sampling, the median and range of the $\mathrm{NT}_{50}$ values were 7627 (2299 - 50640), for Wuhan-hu- 1, but only 60 (<25 - 201 ) for PMS20 and 92 (25 - 327) for Omicron (Figure 3A). These values correspond to mean $( \pm S D)$ loss of potency of $187 \pm 24$ fold for PMS20 and $127 \pm 66$ fold for Omicron. At 5 months after vaccination, neutralizing titer (median and range) in plasmas from the same individuals had waned to $2435(1117-6228)$ for Wuhan-hu-1 and were as low as 43 (<25 - 108) for PMS20 and $126(27-321)$ for Omicron, corresponding to mean ( $\pm S D)$ reductions in $\mathrm{NT}_{50}$ of $58 \pm 23$-fold for PMS20 and $27 \pm 17$-fold for Omicron (Figure 3B). 
medRxiv preprint doi: https://doi.org/10.1101/2021.12.12.21267646; this version posted December 13, 2021. The copyright holder for this preprint (which was not certified by peer review) is the author/funder, who has granted medRxiv a license to display the preprint in perpetuity.

It is made available under a CC-BY-NC-ND 4.0 International license .

Plasmas from J\&J vaccine recipients were particularly poor at neutralizing the variants. Plasma from J\&J vaccine recipients collected 1 month after vaccination had median (and range) $\mathrm{NT}_{50}$ values of $588(167-4177),<25(<25-314)$ and $<25(<25-201)$ for the Wuhan-hu-1, PMS20 and Omicron spike proteins respectively (Figure $3 \mathrm{C}$ ). $\mathrm{NT}_{50}$ values for $\mathrm{J} \& \mathrm{~J}$ recipients were quite stable or even increased in some cases over time, such that at five months after J\&J vaccination $\mathrm{NT}_{50}$ values were $982(52-5597), 36(25-378)$ and $43(<25-368)$ for the Wuhanhu-1, PMS20 and Omicron pseudotypes respectively (Figure 3D). Nevertheless, neutralizing titers in the J\&J vaccinees were sufficiently low, such that quantitative reductions in potency against the PMS20 and Omicron pseudotypes could not be meaningfully calculated because many plasmas did not contain detectable neutralizing activity against these pseudotypes (Figure 3B).

\section{EFFECTS OF mRNA VACCINE BOOSTERS ON NEUTRALIZATION BY CONVALESCENT OR PREVIOUSLY mRNA VACCINATED INDIVIDUALS}

Vaccination of previously infected individuals has previously been shown to substantially elevate neutralizing titers and breadth ${ }^{5,15,22,23}$. Notably, vaccination of convalescent individuals ${ }^{5,15}$ or boosting of an initial vaccine response by administration of a third mRNA (Pfizer/BNT) vaccine dose $>6$ months after the initial series led to the acquisition of substantial neutralizing activity against PMS20 and against Omicron (Figure 4A, B). Specifically, in individuals that were previously infected by SARS-CoV-2 and later vaccinated, the median and range of the NT 50 values was 388872 (98522 - 1304453), 14982 (1699 - 448699) and 8106 (1503 - 56537) for the Wuhan-hu-1, PMS20 and Omicron spike protein pseudotypes respectively (Figure 4A). Analysis of $\mathrm{NT}_{50}$ trajectories for individual vaccine recipients showed that these values represent a median increase in $\mathrm{NT}_{50}$ of 238-fold, 214-fold and 154-fold for Wuhan-hu-1, PMS20 and 
medRxiv preprint doi: https://doi.org/10.1101/2021.12.12.21267646; this version posted December 13, 2021. The copyright holder for this preprint (which was not certified by peer review) is the author/funder, who has granted medRxiv a license to display the preprint in perpetuity.

It is made available under a CC-BY-NC-ND 4.0 International license .

Omicron pseudotypes compared to the pre-vaccination, convalescent titers in the same individuals (Figure 4C).

For individuals that were vaccinated with 2 doses of a Pfizer/BNT or Moderna mRNA vaccines $\sim 6$ months previously and then boosted with a third mRNA (Pfizer/BNT) dose $\sim 1$ month prior to sampling, the median and range of the $\mathrm{NT}_{50}$ values was 65617 (15641 - 341247), 1505 (404 9039) and 3871 (1411 - 21300) for the Wuhan-hu-1, PMS20 and Omicron pseudotypes, representing a comparative deficit in potency of $55 \pm 45$ fold for PMS20 and $18 \pm 14$ fold for Omicron (Figure 4B). Nevertheless, compared to $\mathrm{NT}_{50}$ values measured at 5 months after the second mRNA vaccine dose (prior to the booster) in the same individuals, these boosted titers represent a median (+/-SD) $\mathrm{NT}_{50}$ increase of 26-fold for Wuhan-hu-1, 35-fold for PMS20 and 38fold for Omicron (Figure 4D). We conclude that boosting immunity with mRNA vaccines dramatically increases neutralizing titer and breadth for individuals who had previously been infected with Wuhan-hu-1-like SARS-CoV-2 or vaccinated with Wuhan-hu-1-based mRNA vaccines. In particular, neutralizing titers against Omicron were substantial (1411- 56537) in all infected then vaccinated or three dose mRNA vaccine recipients tested, but low or undetectable in many convalescent unvaccinated or two dose mRNA vaccine recipient individuals (Figure 4C, D).

\section{Discussion}

Compared with previous naturally occurring SARS-CoV-2 variants, Omicron exhibits an unprecedented degree of neutralizing antibody escape. Indeed, the degree of neutralization resistance exhibited by Omicron is similar to that exhibited by PMS20, a designed neutralization resistant spike in which 20 naturally occurring and laboratory selected mutations were aggregated $^{5}$. The similarity in neutralization properties and distribution of changes on the spike protein surface between PMS20 and Omicron argues that a major selective pressure leading to 
medRxiv preprint doi: https://doi.org/10.1101/2021.12.12.21267646; this version posted December 13, 2021. The copyright holder for this preprint (which was not certified by peer review) is the author/funder, who has granted medRxiv a license to display the preprint in perpetuity.

It is made available under a CC-BY-NC-ND 4.0 International license .

the emergence of Omicron was imposed by neutralizing antibodies. Whether this selective pressure occurred in one or more immunocompromised individuals with persistent infection, or populations that have experienced high prevalence infection by waves of prior variants remains unclear.

Of particular concern, neutralizing antibody titers against Omicron were low, even below the limit of detection in a significant fraction of convalescent individuals, Ad26 vaccine recipients or 2 dose mRNA vaccine recipients, particularly following the waning that ensues following infection or vaccination. Nevertheless, individuals that had been previously infected with SARSCoV-2 and subsequently received mRNA vaccines, or those that have received three doses of mRNA vaccines had substantial neutralizing antibody titers against Omicron $\sim 1$ month after boosting. The ability of plasmas from these individuals to neutralize Omicron likely represents the combined effect of increased antibody levels following multiple exposures to antigen, as well as the effects of affinity maturation that can dramatically improve the neutralizing breadth of individual SARS-CoV-2 antibodies as well as polyclonal plasma ${ }^{5,15}$.

These findings suggest that boosting and promoting affinity maturation of the antibodies of those who have previously been infected or vaccinated using existing Wuhan-hu-1 based vaccine immunogens will provide additional protection against Omicron variant infection and disease. The emergence of the Omicron lineage that is phylogenetically distinct from the previously globally dominant Delta SARS-CoV-2 variant also illustrates the need for continuing vigilance and mitigation of virus transmission. The prior emergence, and global spread of the Alpha, Delta, and Omicron variants underscore our inability to predict the emergence of variants that might facilitate targeted vaccine development. The findings described herein and the emergence of Omicron suggest that effort should be devoted to development of vaccination 
medRxiv preprint doi: https://doi.org/10.1101/2021.12.12.21267646; this version posted December 13, 2021. The copyright holder for this preprint (which was not certified by peer review) is the author/funder, who has granted medRxiv a license to display the preprint in perpetuity.

It is made available under a CC-BY-NC-ND 4.0 International license .

strategies that are broadly based rather than, or in addition to, those narrowly targeted at contemporary emergent SARS-CoV-2 variants.

\section{Acknowledgements}

This work was supported by NIH grant R37AI64003 and R01AI501111 (P.D.B).; R01AI78788 (TH); P01-Al138398-S1 (M.C.N.) and 2U19AI111825 (M.C.N.). C.G. was supported by the

Robert S. Wennett Post-Doctoral Fellowship, in part by the National Center for Advancing Translational Sciences (National Institutes of Health Clinical and Translational Science Award program, grant UL1 TR001866), and by the Shapiro-Silverberg Fund for the Advancement of Translational Research. P.D.B. and M.C.N. are Howard Hughes Medical Institute Investigators.

Author contributions P.D.B., T.H., M.C.N., F.S., and F.M. conceived, designed and analyzed the experiments. F.S., Y.W., F.M., J.D.S, and E.B. performed pseudotype neutralization experiments. F.S. constructed expression plasmids. A.C. performed NGS. Y.Z., M.C, C.G. and executed clinical protocols and recruited participants and processed samples. P.D.B., T.H., and M.C.N. wrote the manuscript. 
Table 1. Plasma samples tested for neutralizing activity

\begin{tabular}{|c|c|c|c|c|}
\hline Plasma panel & $N$ & & Description & $\begin{array}{l}\text { Time after infection or } \\
\text { vaccination }\end{array}$ \\
\hline Panel $1^{1}$ & 20 & Convalescent & & $\sim 1 \mathrm{~m}$ post infection \\
\hline Panel $2^{1}$ & 20 & Convalescent & & $\sim 6 \mathrm{~m}$ post infection \\
\hline Panel 3 & 20 & Convalescent & & 1y post infection \\
\hline Panel $4^{2}$ & 18 & Vaccinated & 2 doses of Pfizer mRNA & $\sim 1 \mathrm{~m}$ post $2^{\text {nd }}$ dose \\
\hline Panel $5^{2}$ & 18 & Vaccinated & 2 doses of Pfizer mRNA & $\sim 5 \mathrm{~m}$ post $2^{\text {nd }}$ dose \\
\hline Panel $6^{2}$ & 18 & Vaccinated & 3 doses of Pfizer mRNA & $\sim 1 \mathrm{~m}$ post $3^{\text {rd }}$ dose \\
\hline Panel $7^{3}$ & 19 & Vaccinated & 1 dose J\&J Ad26 & $\sim 1 \mathrm{~m}$ post single dose \\
\hline Panel $8^{3}$ & 19 & Vaccinated & 1 dose J\&J Ad26 & $\sim 5 \mathrm{~m}$ post single dose \\
\hline Panel $9^{1}$ & 17 & $\begin{array}{l}\text { Convalescent } \\
+ \text { Vaccinated }\end{array}$ & $\begin{array}{l}1 \text { or } 2 \text { doses of Pfizer or } \\
\text { Moderna mRNA, following } \\
\text { prior SARS-CoV-2 infection }\end{array}$ & $\begin{array}{l}\sim 12 \mathrm{~m} \text { post infection, } \\
\text { various times post } \\
\text { vaccination }\end{array}$ \\
\hline
\end{tabular}

${ }^{1}$ Plasma panels 1,2 , and 9 from matched convalescent individuals

${ }^{2}$ Plasma panels 4,5 , and 6 from matched mRNA vaccinated individuals

${ }^{3}$ Plasma panels 7 and 8 from matched J\&J Ad26 vaccinated individuals 
A

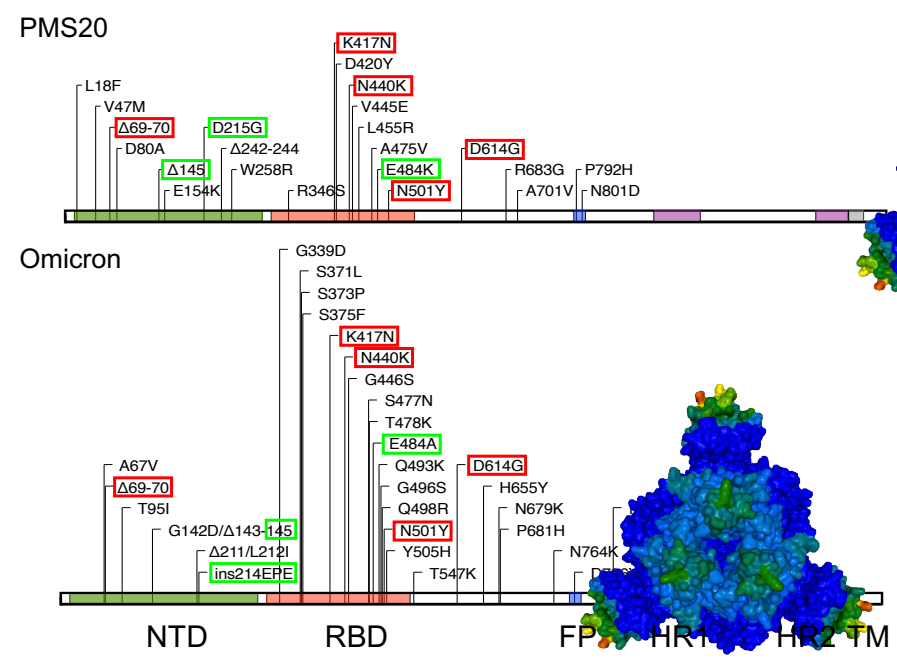

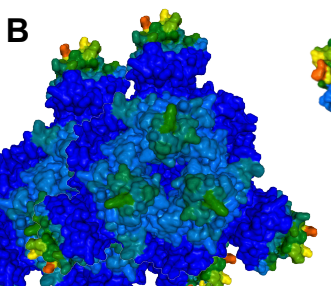
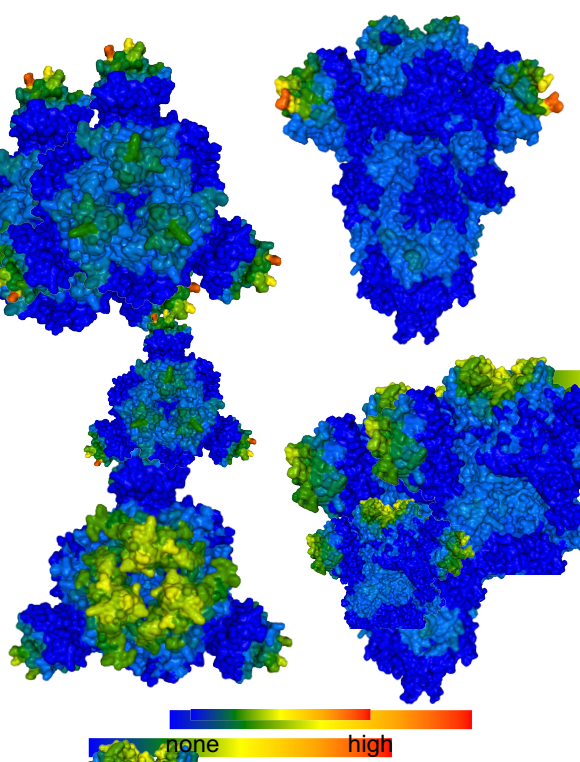

Figure 1. Distribution of mutations in the naturally emergent Omicron variant, and the neutralization resistant designed PMS20 spike proteins.

(A) Schematic diagram of PMS20 and Omicron spike proteins with amino acid changes compared to Wuhan-1 indicated. Red outlines highlight identical changes in PMS20 and Omicron, green outlines indicate nonidentical changes affecting same residues in PMS20 and Omicron. Position of spike features is marked: NTD $=\mathrm{N}$-terminal domain RBD $=$ Receptor Binding Domain, FP = Fusion Peptide, $\mathrm{HR}=$ heptad repeat, $\mathrm{TM}=$ Transmembrane.

(B) Representation of the spatial distribution of mutations on the surface of PMS20 and Omicron spike proteins. Frequency of amino acid changes relative to Wuhan-hu-1 in PMS20 or Omicron projected onto the SARS-CoV-2 spike structure (PDB 6VXX). The average frequency of substitutions in a 15 angstrom radius is represented using a color spectrum (scale 0-40) (https://biostructmap.burnet.edu.au). 

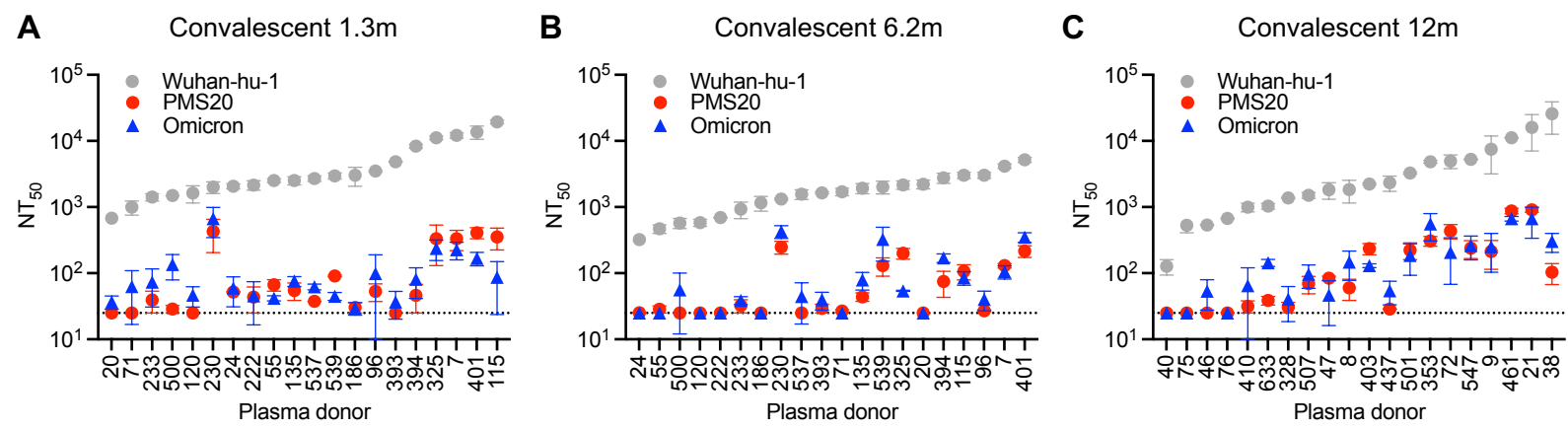

Figure 2. Plasma neutralizing titers against Wuhan-hu-1, PMS20 and Omicron SARS-CoV2 variants in convalescent, unvaccinated individuals

$(A-C) N T_{50}$ values of plasmas collected at 1 month $(A), 6$ months $(B)$ and 12 months $(C)$ after SARS-CoV-2 infection against Wuhan-hu-1, PMS20 and Omicron spike pseudotyped reporter viruses. Each $\mathrm{NT}_{50}$ was determined in two independent experiments (each with two technical replicates). The median and range of the two independent determinations is plotted. Dashed line indicates the lowest plasma dilution tested (1:25). 
A

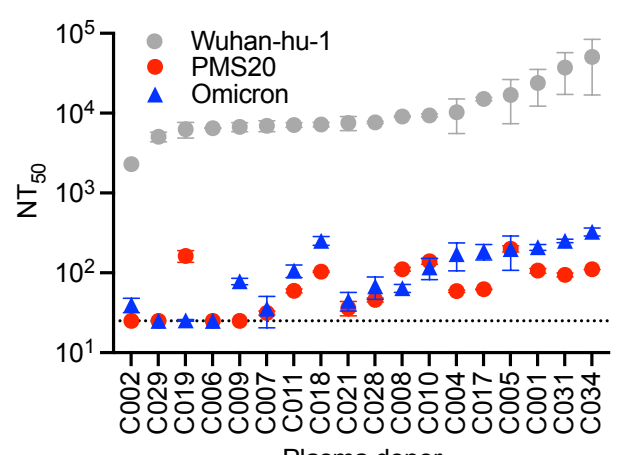

Plasma donor

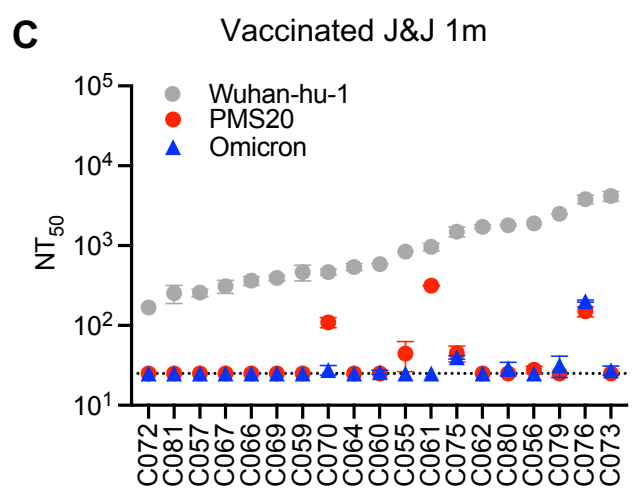

Plasma donor
B Vaccinated mRNA $5 \mathrm{~m}$

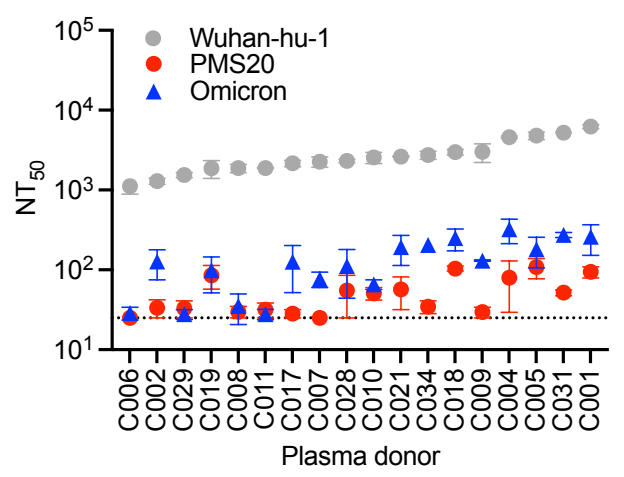

D Vaccinated J\&J $6 \mathrm{~m}$

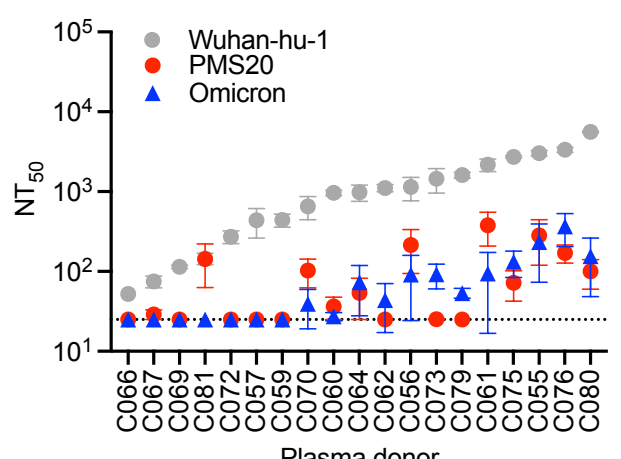

Plasma donor

Figure 3.

Plasma neutralizing titers against Wuhan-hu-1, PMS20 and Omicron SARS-CoV-2 variants in vaccine recipients

(A, B) $N T_{50}$ values of plasmas from recipients of standard 2 dose mRNA (Pfizer/BNT or Moderna) approximately one (A) and five (B) months after vaccination.

$(C, D) N_{50}$ values of plasmas from recipients of single dose Ad26 (J\&J) SARS-CoV-2 vaccines approximately one (C) and five (D) months after vaccination.

For each panel, $\mathrm{NT}_{50}$ were determined in two independent experiments (each with two technical replicates). The median and range of the two independent determinations is plotted. Dashed line indicates the lowest plasma dilution tested (1:25) 
medRxiv preprint doi: https://doi.org/10.1101/2021.12.12.21267646; this version posted December 13, 2021. The copyright holder for this preprint (which was not certified by peer review) is the author/funder, who has granted medRxiv a license to display the preprint in perpetuity.

It is made available under a CC-BY-NC-ND 4.0 International license .

A Infected then vaccinated (mRNA)

B Vaccinated (mRNA) 3rd dose (Pfizer)
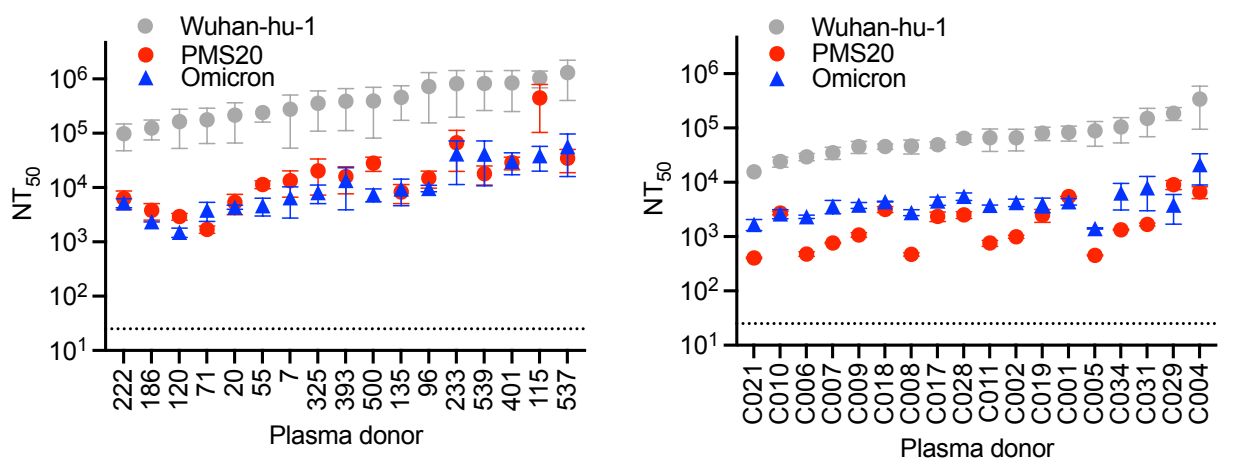

C Infected then vaccinated (mRNA)
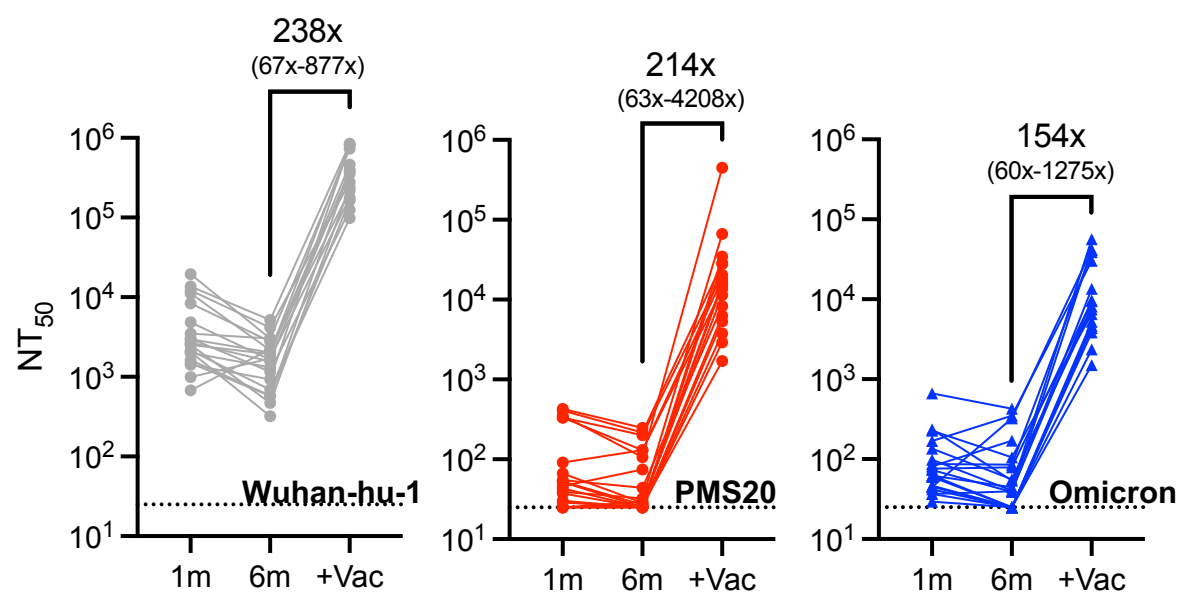

D Vaccinated (mRNA) 3rd dose (Pfizer)
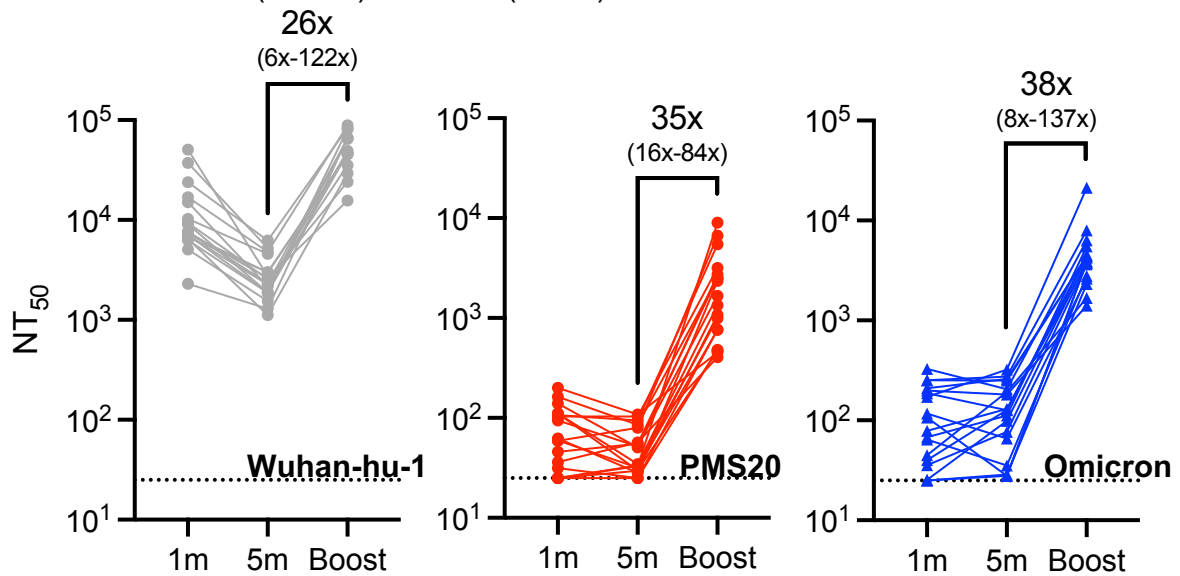

Figure 4. Effect of vaccinating previously infected individuals or boosting previously vaccinated individuals on Wuhan-hu-1, PMS20 and Omicron plasma neutralizing titers. (A) $\mathrm{NT}_{50}$ values of plasmas from recipients of mRNA (Pfizer/BNT or Moderna) vaccines subsequent to infection with SARS-CoV-2.

(B) $\mathrm{NT}_{50}$ values of plasmas from recipients of three doses of mRNA (Pfizer/BNT or Moderna) vaccines with the third dose (Pfizer/BNT) administered $>6 \mathrm{~m}$ after the second. For $(\mathrm{A})$ and $(\mathrm{B})$ each $\mathrm{NT}_{50}$ was determined in two independent experiments (each with two technical replicates). 
medRxiv preprint doi: https://doi.org/10.1101/2021.12.12.21267646; this version posted December 13, 2021. The copyright holder for this preprint (which was not certified by peer review) is the author/funder, who has granted medRxiv a license to display the preprint in perpetuity.

It is made available under a CC-BY-NC-ND 4.0 International license .

The median and range of the two independent determinations is plotted. Dashed line indicates the lowest plasma dilution tested (1:25).

(C) Trajectories of $\mathrm{NT}_{50}$ values against Wuhan-hu-1, PMS20, and Omicron pseudotypes, as indicated, for convalescent individuals measured 1 month and 6 months after infection and then following subsequent vaccination (+Vac).

(D) Trajectories of $\mathrm{NT}_{50}$ values against Wuhan-hu-1, PMS20, and Omicron pseudotypes, as indicated, for mRNA vaccinated individuals measured 1 month and 5 months after the second dose and 1 month after the third dose (Boost). 


\section{References}

1. https://www.gisaid.org/G.

2. Torjesen I. Covid-19: Omicron may be more transmissible than other variants and partly resistant to existing vaccines, scientists fear. Bmj 2021;375:n2943. (In eng). DOI: 10.1136/bmj.n2943.

3. Karim SSA, Karim QA. Omicron SARS-CoV-2 variant: a new chapter in the COVID-19 pandemic. Lancet 2021 (In eng). DOI: 10.1016/s0140-6736(21)02758-6.

4. Hoffmann M, Kleine-Weber H, Pöhlmann S. A Multibasic Cleavage Site in the Spike Protein of SARS-CoV-2 Is Essential for Infection of Human Lung Cells. Mol Cell 2020;78(4):779-784.e5. (In eng). DOI: 10.1016/j.molcel.2020.04.022.

5. Schmidt $F$, Weisblum $Y$, Rutkowska $M$, et al. High genetic barrier to SARS-CoV-2 polyclonal neutralizing antibody escape. Nature 2021 (In eng). DOI: 10.1038/s41586021-04005-0.

6. Baum A, Fulton BO, Wloga E, et al. Antibody cocktail to SARS-CoV-2 spike protein prevents rapid mutational escape seen with individual antibodies. Science (New York, NY) 2020;369(6506):1014-1018. (In eng). DOI: 10.1126/science.abd0831.

7. Weisblum $Y$, Schmidt $F$, Zhang F, et al. Escape from neutralizing antibodies by SARS-CoV2 spike protein variants. eLife 2020;9:e61312. (In eng). DOI: 10.7554/eLife.61312.

8. Liu L, Wang P, Nair MS, et al. Potent neutralizing antibodies against multiple epitopes on SARS-CoV-2 spike. Nature 2020;584(7821):450-456. (In eng). DOI: 10.1038/s41586-0202571-7. 
9. Robbiani DF, Gaebler C, Muecksch F, et al. Convergent Antibody Responses to SARSCoV-2 Infection in Convalescent Individuals. Nature 2020;584:437-442.

10. Greaney AJ, Loes AN, Crawford KHD, et al. Comprehensive mapping of mutations in the SARS-CoV-2 receptor-binding domain that affect recognition by polyclonal human plasma antibodies. Cell host \& microbe 2021;29(3):463-476. (In eng). DOI: 10.1016/j.chom.2021.02.003.

11. Guy AJ, Irani V, Richards JS, Ramsland PA. BioStructMap: a Python tool for integration of protein structure and sequence-based features. Bioinformatics (Oxford, England) 2018;34(22):3942-3944. (In eng). DOI: 10.1093/bioinformatics/bty474.

12. Guy AJ, Irani V, Beeson JG, et al. Proteome-wide mapping of immune features onto Plasmodium protein three-dimensional structures. Scientific reports 2018;8(1):4355. (In eng). DOI: 10.1038/s41598-018-22592-3.

13. Gaebler C, Wang Z, Lorenzi JCC, et al. Evolution of antibody immunity to SARS-CoV-2. Nature 2021;591:639-644. (In eng). DOI: 10.1038/s41586-021-03207-w.

14. Muecksch F, Weisblum Y, Barnes CO, et al. Affinity maturation of SARS-CoV-2 neutralizing antibodies confers potency, breadth, and resilience to viral escape mutations. Immunity 2021 (In eng). DOI: 10.1016/j.immuni.2021.07.008.

15. Wang Z, Muecksch F, Schaefer-Babajew D, et al. Naturally enhanced neutralizing breadth against SARS-CoV-2 one year after infection. Nature 2021;595(7867):426-431. (In eng). DOI: 10.1038/s41586-021-03696-9.

16. Moriyama S, Adachi Y, Sato T, et al. Temporal maturation of neutralizing antibodies in COVID-19 convalescent individuals improves potency and breadth to circulating SARS- 
CoV-2 variants. Immunity 2021;54(8):1841-1852.e4. (In eng). DOI:

10.1016/j.immuni.2021.06.015.

17. Cho A, Muecksch F, Schaefer-Babajew D, et al. Anti-SARS-CoV-2 receptor-binding domain antibody evolution after mRNA vaccination. Nature 2021 (In eng). DOI: 10.1038/s41586-021-04060-7.

18. Sakharkar M, Rappazzo CG, Wieland-Alter WF, et al. Prolonged evolution of the human B cell response to SARS-CoV-2 infection. Science immunology 2021;6(56) (In eng). DOI: 10.1126/sciimmunol.abg6916.

19. Hurlburt NK, Seydoux E, Wan YH, et al. Structural basis for potent neutralization of SARS-CoV-2 and role of antibody affinity maturation. Nature communications 2020;11(1):5413. (In eng). DOI: 10.1038/s41467-020-19231-9.

20. Wang $Z$, Schmidt $F$, Weisblum $Y$, et al. mRNA vaccine-elicited antibodies to SARS-CoV-2 and circulating variants. Nature 2021;592(7855):616-622. (In eng). DOI: 10.1038/s41586-021-03324-6.

21. Schmidt F, Weisblum Y, Muecksch F, et al. Measuring SARS-CoV-2 neutralizing antibody activity using pseudotyped and chimeric viruses. The Journal of experimental medicine 2020;217(11):e20201181. (In eng). DOI: 10.1084/jem.20201181.

22. Ebinger JE, Fert-Bober J, Printsev I, et al. Antibody responses to the BNT162b2 mRNA vaccine in individuals previously infected with SARS-CoV-2. Nature medicine 2021;27(6):981-984. (In eng). DOI: 10.1038/s41591-021-01325-6. 
medRxiv preprint doi: https://doi.org/10.1101/2021.12.12.21267646; this version posted December 13, 2021. The copyright holder for this preprint (which was not certified by peer review) is the author/funder, who has granted medRxiv a license to display the preprint in perpetuity.

It is made available under a CC-BY-NC-ND 4.0 International license .

23. Stamatatos L, Czartoski J, Wan $\mathrm{YH}$, et al. mRNA vaccination boosts cross-variant neutralizing antibodies elicited by SARS-CoV-2 infection. Science (New York, NY) 2021 (In eng). DOI: 10.1126/science.abg9175. 